\title{
Reading Power: Muslims in the War on Terror Discourse
}

\section{Dr. Uzma Jamil}

Postdoctoral Research Fellow at the International Centre for Muslim and NonMuslim Understanding at the University of South Australia.

ISLAMOPHOBLA STUDIES JOURN AL VOLUME 2, NO. 2, FALL 2014, PP. 29-42.

Published by:

Islamophobia Research and Documentation Project,

Center for Race and Gender, University of California, Berkeley.

Disclaimer:

Statements of fact and opinion in the articles, notes, perspectives, etc. in the Islamophobia Studies Journal are those of the respective authors and contributors. They are not the expression of the editorial or advisory board and staff. No representation, either expressed or implied, is made of the accuracy of the material in this journal and ISJ cannot accept any legal responsibility or liability for any errors or omissions that may be made. The reader must make his or her own evaluation of the accuracy and appropriateness of those materials. 


\title{
Reading Power: Muslims in the War on Terror Discourse
}

\author{
Dr. Uzma Jamil \\ Postdoctoral Research Fellow at the International Centre for Muslim and \\ Non-Muslim Understanding at the University of South Australia
}

\begin{abstract}
This paper analyzes the relationship between Muslims and the west defined at a particular moment in post 9/11 America and the war on terror context through a conversation in the novel The Submission (2011) by Amy Waldman. It critiques the construction of knowledge about Muslims and how this knowledge functions as part of a hegemonic discourse of Orientalism. The novel is about a public competition for an architectural design for a memorial marking the site of the World Trade Centre attacks in New York City. Khan is the architect who wins the competition through a blind selection process. But when his identity is revealed, public controversy erupts. Claire, the other protagonist in this encounter, is a white woman with two children, widowed in the 9/11 attacks. She is also a member of the selection committee. While Claire's assumptions denote western, hegemonic representations that define Muslims in narrow ways, Khan's responses represent a critique of this Orientalist construction, as well as indicating how it can be reshaped, with all the tension that this process provokes. This fictional encounter offers an opportunity to reflect on decolonial possibilities in the 'real life' encounter between Muslims and the west in the war on terror context.
\end{abstract}

Keywords: Muslim; war on terror; power relations; Orientalism

\section{INTRODUCTION}

Although $9 / 11$ is often used to mark a watershed moment in world events, it illustrates political continuities in the relationship between Islam, Muslims and the west. The 'war on terror' discourse emerging from the 9/11 attacks ties together terrorism, national security, war and Muslims, reinforcing Orientalist narratives about Muslims as 'inherently' violent, threatening and as potential terrorists. This contemporary discourse has both political and epistemological dimensions: the politics of how Muslims are situated in the war on terror in relation to the west is linked to the construction of knowledge about Muslims and the possibilities for how they are and can be known in the west.

This paper elaborates on these two dimensions through the analysis of a fictional encounter in the novel, The Submission (2011) by Amy Waldman. The novel is about a public competition for an architectural design for a memorial marking the site of the World Trade Centre attacks in New York City. Khan wins the competition through a blind selection process. But when his identity is revealed, public controversy erupts over his Muslim identity. Claire, the other protagonist in this encounter, is a white, liberal, middle-class woman with two children, widowed in the 9/11 attacks. She is also a member of the 
selection committee. Their conversation takes place in a meeting arranged by the head of the selection committee to discuss the public controversy and his winning design for a memorial garden.

Their conversation revolves around two main questions. Who speaks for and about Islam and Muslims in the west? Who constructs the categories used to give meaning to the Muslim subject in the war on terror? The answer involves an analysis of the hegemonic configuration of power and meaning in their encounter. This paper is divided into four sections. In the first section, I introduce the American war on terror discourse. In the second section, I discuss the construction of Orientalism and how it is relevant in the war on terror discourse today as a hegemonic system of power and meaning. In the third section, I analyze the conversation between the two characters and lastly, I discuss how this encounter illustrates the power of Orientalism as a hegemonic discourse and its critique, including issues of Muslim agency, the construction of meaning and the implications for creating a decolonial space for Muslims in the world today.

\section{THE AMERICAN WAR ON TERROR DISCOURSE}

The "war on terror" was named by the Bush administration in September 2001 to mark the American response to the 9/11 attacks and to identify those "who are with us" and those "who are with the terrorists." Despite the fluidity of the phrase, the American war on terror took multiple, concrete forms. It included international military interventions in Afghanistan and Iraq, domestic national security legislation and measures targeting Muslim populations and the revitalization of an Orientalist cultural discourse about Islam versus the west as an explanation for the $9 / 11$ attacks.

Traced through Bush's speeches, the war on terror discourse situated Americans as "good", "innocent victims" and the attackers as "evil perpetrators." Through these categories of good and evil, the story of 9/11 was elevated to the level of a national sacred myth in American public discourse. ${ }^{2}$ Using the formulaic "good guys" versus "bad guys" scenario from classic Western movies, ${ }^{3}$ Bush presented America and its allies as "noble" heroes and defenders of freedom, liberty and democracy throughout the world. The "we" also discursively included "the civilized world", "moderates" and "the coalition" in addition to the United States. On the other side was "the enemy," terrorists who were hateful, evil, murderous and violent. This enemy was presented as a fluid category, including Osama Bin Laden, al-Qaeda, Saddam Hussain, Iran and other 'rogue' elements at large."

This dominant American discourse presented terrorism as ahistorical, outside the timeline of history, creating a contradiction; America had a historic role to play in the war on terror, but terrorism itself was not historically derived. Terrorism was also presented as a threat without any political roots. The terrorists did not have any political grievances; they were simply evil and violent. Lastly, terrorism was also juxtaposed against freedom as an ideology, stressing the boundaries between the U.S. and the terrorists as actors from opposite sides of a moral divide in this discourse. ${ }^{5}$ Furthermore, these two opposites could only exist in relation to each other. The existence of the "terrorists" allowed the Americans to be constructed as "heroes." One side could be framed meaningfully only in relation to the other.

While most people did accept this American discourse, the circulation of $9 / 11$ conspiracy theories represented a challenge to it. Through casting doubt on the 'truth' of the 'official' story of $9 / 11$, they represent a critique of the relationship between discourse, power 
and 'truth.' They also illustrate a different understanding of power, and particularly the hegemonic position of American power in the world. ${ }^{6}$

\section{ORIENTALISM AND THE WAR ON TERROR}

This brings us to consider the concepts of hegemony and power in the war on terror discourse, which is linked to Orientalism as a hegemonic discourse. I draw on a neoGramscian conceptualization of hegemony ${ }^{7}$ as a type of political relation that is contingent. It is temporary, precarious and constructed through the inclusion of some possibilities of meanings and the exclusion of others. This is dependent on there being space for these meanings to shift, as we will see in the encounter in the novel. Hegemony is synonymous with power relations, in that power does not exist outside of hegemony. Hegemony is articulated through a particular set of power relations attached to a system of meaning. "Hegemonic practices are the practices of articulation through which a given order is created and the meaning of social institutions is fixed."

Orientalism is a hegemonic discourse "based upon an ontological and epistemological distinction made between 'the Orient' and (most of the time) 'the Occident." "This relationship operates through the superiority of the west, its ideas and its ways of being and doing as the reference point. Through Orientalism, the west is been able to exercise its dominant position by structuring how the Orient is "dealt with": "by making statements about it, authorizing views of it, describing it, by teaching it, settling it, ruling over it: in short, Orientalism as a Western style for dominating, restricting and having authority over the Orient."10

At a discursive level, this means that western power structures the possibilities for what is thought and said about the Orient, ${ }^{11}$ to the extent that "the Orient itself becomes a creation of orientalism." "12 Described as "strong orientalism," this aspect of Said's argument suggests that the construction of the Orient itself is a reflection of western fantasies of its Other, rather than simply the distortion of the 'real' Orient by Western scholars. ${ }^{13}$

The power of Orientalism as a hegemonic discourse is illustrated in how it "creates" knowledge about Islam and Muslims. This knowledge is identified through "certain distinct and intellectually knowable lines." ${ }^{14}$ First, that there is an absolute difference between the Orient and the west. The west is constructed as superior, rational, civilized and modern, while the Orient is constructed negatively as primitive, uncivilized, and violent. ${ }^{15}$ Second, "the Orient is eternal, uniform and incapable of defining itself." ${ }^{16}$ As a result, not only must it always be represented and spoken for by the west, but the west's knowledge about the Orient is deemed the only legitimate and "objective" knowledge. Last, the Orient is something to be either feared or mastered. ${ }^{17}$

These themes emerge consistently in the ways that Islam and Muslims continue to be described today. Orientalism has become normalized as an expression of western privilege and a form of coloniality in the contemporary context. ${ }^{18}$ Critiquing the structures of powerknowledge that underpin this hegemonic discourse involves pointing out its contingency, how it is reinforced and perpetuated through various issues, in this case through the war on terror discourse.

The war on terror discourse reinforces the basic premise of Orientalism, the absolute difference between Islam and the west. Islam and Muslims are associated with an "inherent," uncivilized propensity for violence, which is connected to the Orient as something to be both feared and controlled for this reason. This fear of the violent potential of the Muslim Other takes its contemporary form through the trope of "dangerous Muslim man" who 
evokes fear through terrorism, anchored by the civilized, white, "good", heroic American on the other side. ${ }^{19}$ This American is part of the construction of the western "family of white nations, a civilization, obliged to use force and terror to defend itself against a menacing cultural Other." 20

A second way in which the war on terror discourse extends Orientalist constructs is through the idea of an unchanging and uniform Muslim Other who cannot speak for her/himself. This is about two issues: first, the idea that all Muslims everywhere are the same, and second, the agency of Muslims to define themselves. They can only be seen and heard if they are interpreted and mediated by the west through its privilege to both set the terms of the discourse of the war on terror and to define them as particular types of Muslims through it. The subject positions available to Muslims in this hegemonic discourse are linked to the way in which terrorism is defined as an "Islamic" problem because Muslims carried out the 9/11 attacks. Terrorism is explained as a religious problem, rather than as a political issue, by linking it to the religion of the attackers. By association then, all Muslims have this "inherent" tendency to be potential terrorists because they are Muslims. Their actions can be explained solely and exclusively through reference to their religion, which is also perceived as "inherently" violent. Quranic verses are often presented as literal evidence of this Muslim propensity for "Islamic" terrorism.

This is then further linked to the idea that Muslims - all Muslims everywhere - must take moral responsibility for the 9/11 attacks because they are all Muslim. Thus, they are asked to denounce terrorism and to apologize for the actions of others on the basis that their shared religion is responsible for the violence. And they are asked to do this, not just once after the 9/11 attacks, but after every terrorist incident, or attempt, involving Muslims anywhere in the world. The criticism that 'Muslims are not doing enough to condemn terrorism' is often circulated in the media after any such event. Through this, Muslims are asked to soothe the fears of the west and to defuse their anxieties by reassuring them that they are "good Muslims" or "moderate Muslims," 21 not the violent, blowing-up-things kind of "bad Muslims." However, both "good Muslims" and "bad Muslims" confirm and validate the superior position of the west in relation to the violent and threatening Muslim Other.

Orientalism underpins the war on terror discourse; from the way that terrorism and the 9/11 attacks are framed to the subject positions available to Muslims in this discourse. This hegemonic system of meaning underpins the securitization process through which Muslims are constructed as threats and as "suspect" and "disloyal" citizens in America. ${ }^{22}$ It justifies how state power is used to profile and target Muslims as part of national antiterrorism efforts. One prominent illustration of this is the 2002-2003 NSEERS (National Security Exit-Entry Registration System), approving the registration, detention and deportation, of non-immigrant Muslim men in the US from a pre-determined list of 25 predominantly Muslim countries. ${ }^{23}$ This process did not net any terrorist "sleeper cells," but did disrupt families, communities and neighborhoods, while cementing the public's negative perception of Muslims as both collectively guilty and threatening. Since then, the power of the American state to single out Muslims in the name of national security has only increased, evidenced through the revelations from Snowden of NSA and FBI spying on prominent Muslim leaders in America. ${ }^{24}$ 


\section{THE ENCOUNTER}

Although fiction, Amy Waldman's novel The Submission, deals with issues around the construction of national identity, public memory and the limits of public discourse. Coincidentally, this novel came out around the time (2010-2011) that a Muslim community center, Park 51, was facing tremendous protest in Manhattan. Dubbed the "Ground Zero Mosque" by its critics because it was near the site of the 9/11 attacks, it was planned as a conversion of an existing building to provide both prayer space and space for community programs and activities. ${ }^{25}$ The public controversy around it employed similar assumptions about Islam, Muslims and terrorism illustrated in the novel. ${ }^{26}$

The main plot of the book revolves around a public competition for an architectural design for a memorial marking the site of the World Trade Centre attacks in New York City. The conversation that is the focus of this paper is between Mohammad Khan, the architect who wins the competition with a design for a memorial garden and Claire Burwell, a white woman who is a member of the selection committee and a 9/11 widow. The purpose of the meeting between them is to discuss the public controversy over Khan's winning design.

The meeting is narrated from Claire's perspective, indicative of her superior position in this encounter and her privilege as a white, American woman. In contrast, the reader is not privy to Khan's thoughts or motivations. We only see his words and actions, and how Claire interprets his words and actions. But even in this apparent hierarchical dynamic, the reader is given room to read between the lines and interpret his words and the implications behind them. On the surface, though it appears that Khan is in a subordinate position, his actions and words demonstrate otherwise.

The meeting opens with Clair feeling uncomfortable. She wonders "whether Paul Rubin had deliberately procured the smallest space possible at his old bank in which to cage her with Mohammad Khan. She and he were seated in uncomfortable proximity, across a narrow metal table, the walls too near their backs." ${ }^{, 7}$ She feels that the proximity to him is restrictive, perhaps indicative of being imprisoned with someone she doesn't feel comfortable with, the Muslim Other. This proximity forces engagement with the Other. "They were so close they had no choice but to look directly into each other's eyes." ${ }^{28}$ The configuration of the physical space undermines her comfort in her usually superior position because they are required to face each other and to look at each other directly, evenly, across the plane of the table.

While Claire feels anxious, Khan projects confidence. "Khan's comfort with his physical self, long and lean, struck her forcibly in this space...His confidence had been restored, and somehow this unnerved her." ${ }^{29}$ This is a man who is comfortable in his own skin, who does not feel the need to be someone, or something else, and she finds this unsettling, partially because he does not fit her fantasy image of him. "In her dream, his face held warmth, the desire to explain. Here it simply withheld. His affect was dispassionate.",30 She wants him to engage with her emotionally in order to explain that he is not a threat and to reassure her. Through this willingness to explain and reassure, he will confirm her superior position as the one who requires this response, and further the terms of engagement of the war on terror discourse according to which Americans are the innocent victims and "good Muslims" must reassure them by confirming their moral innocence.

One of the main and recurring themes of this encounter is knowledge and the certainty of knowledge of and about Muslims. This is also linked to the question of meaning. 
Ostensibly, the purpose of this meeting is to discuss the meaning of the design of his memorial garden. Claire wants to know what the design means and she wants Khan to tell her. She believes he owes her an explanation of what it means because she supported it. "I can't go on backing the Garden without knowing more," she says to him. ${ }^{31}$ The presumption of privilege on her part is displayed not just in her belief that she has a right to ask, but further, that he is required to tell her. The second assumption of privilege is that there is a meaning, a deeper meaning that can be known with certainty, if only he will tell her. He doesn't respond directly to her assumptions, but suggests she get on with her questions.

The conversation between them occurs in rounds, like a back and forth exchange, point, counterpoint, question, answer. But these rounds can also be read as a spiral, a conversation that circles around the same themes over and over, but becoming more tense in each round, as it moves towards a denouement. In each round then, as the hegemonic assumptions associated with Claire's position of privilege become more explicit, Khan's resistance, which can be read as counter-hegemonic, also becomes more overt.

In the first round, Claire begins by trying to pin down the meaning of the design through where he has traveled. She asks him if he has spent time in any "Islamic countries" and he answers, "Only briefly." She asks him which ones, and he says, "Afghanistan. Dubai, if five hours in the airport counts as spending time." She asks him what he was doing there. "Representing my firm in the competition to design a new American embassy in Kabul, although I'm not sure what bearing that has on the memorial." ${ }^{32}$ Claire is trying to draw a clear line between him being a Muslim and his spending time overseas in "Islamic countries" in order to determine the meaning of the garden design. Although he answers, he doesn't give her the answer she wants.

She drops that line of questioning and moves to a second round. Claire asks, "Where did your idea come from - for the Garden?" "From my imagination," he answers. "Of course, she said after a beat. Of course. But you must have to feed your imagination. Constantly, he said evenly. She couldn't tell if he was joking." Again he answers her question, but he is not explaining things to her satisfaction. She continues on. "You said you fed it, your imagination, in the case of your design, with Islamic gardens. That's what you said at the hearing." He answers, "I said the gardens we now call Islamic were one influence." Khan's answer once again challenges her desire for a concrete, singular answer to the meaning of the design. His answer insists on ambiguity, on the possibility of imagination, creativity, multiple sources of influence, and not just one, reduced down to "Islamic."

Claire persists in drawing a literal connection, asking him whether he was inspired by gardens in Afghanistan. "I did see a garden there, yes," he answers. "And what was it for what's its purpose? I mean - Afghanistan must be full of martyrs. Clumsy, but she had to know." 33 Again, she iterates the importance of knowledge and the certainty of her knowledge, which is based on his fitting into her assumptions.

This moment marks a point where the conversation passes from an indirect to a direct engagement with the terms of hegemony. Up till then, Khan resists Claire by not being friendly and reassuring, by not explaining, by not giving her the answers she wants, and disrupting her by giving answers that do not go in the direction she wants to take the conversation. But in response to her questions, he now says, "So that's why we're here," rendering explicit the hierarchy, that he is there in a subordinate position to answer to her questions and assumptions. In the subsequent conversation, his resistance is also much more explicit, as he begins to question the legitimacy of the system of meaning itself and not just her privileged position within it. 
Moving into the third round, Claire asks the question more openly. She says, "You've never answered that question, about whether it's a martyr's paradise or a paradise at all. Since the question was raised by the Times. You've never said." His response challenges the framing of the question, as he continues to refuse to answer. "The question, as I recall, of it being a 'martyrs' paradise - he mimed quotes around the phrase - was first raised by Fox," he answers. She insists that it doesn't matter who raised it, but its been raised and left hanging. "Where it will hang forever, he said... Why should I be responsible for assuaging fears I didn't create?" 34

This round raises the issue of Muslim agency and representation - who speaks for and about Muslims? He mimes quotes around the phrase 'martyrs' paradise' in order to be ironic perhaps, but also to distance himself from it. It is not his phrase, and therefore he doesn't feel the need to answer to it. It is also a critique of the terms of discourse - who defines the terms used to talk about Muslims. Khan challenges the use of the phrase to ascribe meaning to his design as well as the hegemonic discourse used to construct that category of meaning.

Khan's answer also speaks directly to the issue of collective moral responsibility placed upon Muslims to assuage the fears of the majority. It refers back to the earlier contrast between his aloof and confident demeanor and Claire's fantasy image of him as as "good Muslim," someone who seeks to explain and reassure her. Here, Khan explicitly refuses to take responsibility, and further, to explain or reassure. She insists, "But Paul said you would answer my questions." "I told him I would answer whatever questions I could," he responds. Not only does he not answer, he explicitly refuses to engage with the hegemonic order requiring him to be in the subordinate position of answering.

The conversation circles, coming around again in the fourth round to the question of the "real" meaning of the design and Claire's desire to know what it means. In response, Khan draws two intersecting lines on a piece of paper and asks her to identify them. She describes it as a cross or an X. He draws a square around it and asks her what it is. She gives several possibilities, a window, a checkerboard, a map of Manhattan. "It's all of those things, or maybe none of them. It's lines on a plane, just like the Garden." 35 Through this example, he counters her reading of his design as an "Islamic" design. He goes on to give several examples of modernist, abstract architects and artists, none of whom were Muslim, arguing that their identities were not read into their work. In contrast, she insists that his "lines on a plane" should be understood exclusively as "Islamic" because he is a Muslim. Once again, Khan refuses to take responsibility for her assumptions. "I can't help the associations you bring because I am" [Muslim], he states. ${ }^{36}$

Undeterred, Claire goes on to elaborate exactly what she wants him to do to change the design to fit her meaning. "Take out the canals, so your opponents won't be able to say it's the paradise in the Quran. 'Gardens beneath which rivers flow,' or whatever that line is...Just some symbolic change, as much to show you are eager to find common ground, that you're flexible, as for any substantive reason." He repeats what she has just said. "You want me to take out the canals because it reminds you of a line in the Quran," he said as if he hadn't understood."

This exchange demonstrates that her demand to "know" what the design means is actually a demand to change it. First, she has already decided she knows what it means, that "knowledge" is already settled, fixed. It is not open to interpretation or question, least of all from the subject of that knowledge, the Muslim architect who drew it. What she seeks is confirmation from Khan for what she already believes. This belief is her "knowledge," based on Orientalist construct that has already settled what Muslims are supposed to be like. They 
are defined through an unwavering commitment to Islam, in this case exemplified as a literal depiction of Quranic text.

The second aspect in this exchange is her assumption that he should accept the discourse that creates and defines him. She wants him to accept her belief as the meaning of the design and then change his design and himself to fit into it, to demonstrate his "flexibility" and "eagerness" to compromise. Claire is completely oblivious to his reluctance, privileging her perspective and her comfort. "I'm not going to apologize for wanting to be comfortable with the design for my husband's memorial," Claire said with exasperation. "Your design becomes more threatening if you won't change it." 37 In fact, it is he who becomes threatening if he won't change his design according to her interpretation, or if he isn't willing to be "flexible" enough to accept her privileged position.

The conversation moves towards its final rounds, becoming more intense as Claire finally drops the issue of the design and asks him to take moral responsibility for the terrorist attacks because he's a Muslim.

Followers of your religion have caused enormous pain. Caused me enormous pain. And for all of us, it's very difficult to sort out what Islam actually means or encourages. What Muslims believe. A lot of Muslims who would never commit terrorism still support it, for political reasons if not religious ones. Or they pretend it wasn't Muslims at all who did this. So it's not unreasonable for me to ask where on that continuum you sit. To learn at the hearing that you're never denounced the attack - I'll be honest, that was upsetting. Why haven't you?

Khan says that no one has ever asked him to. She insists, "And if I ask you now?" He doesn't answer, saying that it is an issue of principle. Claire gets angry. "What is the principle behind refusing to say a terrorist attack was wrong, or that you believe in the theology that spawned it?" He counters, "And what is the principle behind demanding that I say it, when your six-year-old son can you it's wrong?... Wouldn't you assume that any nonMuslim who entered this competition thinks that attack was wrong? Why are you treating me differently? Why are you asking more of me?" "Because you're asking more of us!" she said. "You want us to trust you even though you won't answer questions about your design - what it means, where it came from." 38

Her distrust and suspicion are overt, exposing also her assumptions that have structured the entire conversation: her white, western privilege, her "us" against his "them", her belief that he is a Muslim who cannot be trusted, who has a hidden agenda, who is threatening, and who is responsible for terrorism. She tries to explain to him, "This isn't about you - it's about the religion," 39 thus exposing her Orientalist understanding of him as a Muslim.

This is the final turn in this spiraling conversation. Khan turns the construct around to put it back on her. "How would you feel if I justified what happened to your husband by saying it wasn't about him but about his country and its policies- damn shame he got caught up in it, that's all - but you know, he got what he deserved because he paid taxes to the American government." 40

This moral equivalence shocks her, even as it confirms what she already thinks. "It pained her, sickened her...that Khan did see Cal as mere collateral damage in a war American had brought on itself, that he believed Cal, generous, good natured Cal, bore responsibility, guilt, simply because he was American." ${ }^{41}$ Her thoughts illustrate the 
essentialized moral categories underlying the war on terror discourse, between "good Americans" and "evil Muslims." But the denial of her husband's humanity, his individual personality, and his reduction to an American taxpayer undoes her and ejects her from this spiraling conversation. "She jerked to her feet like a mishandled marionette, grabbed her purse, and in one unbroken gesture reached the door, flung it open, stepped through, and slammed it behind her." ${ }^{42}$

\section{MUSLIM AGENCY AND KNOWLEDGE}

This encounter is a confrontation between Orientalism and its critique. It demonstrates the hegemonic discourse of Orientalism and counter-hegemonic responses to it, played out through Claire and Khan. Claire's assumptions about Khan, her beliefs about the meaning of his design and her unerring confidence that her perspective is the only one, is illustrative of the power of Orientalism as a hegemonic discourse to define what Islam and Muslims are and what they can be. Her subject position comes from within this western privilege. Khan is part of this hegemonic system as well. He recognizes it, but his position is different. He questions its legitimacy and highlights its contingency through his resistance to and questioning of her assumptions and privilege. Taking the idea that every hegemonic order could be constructed otherwise, that meanings and configurations of power can shift, he points out this "otherwise." He emphasizes Muslim agency as a counter-hegemonic practice.

There is a gap between what the garden design means to Khan, the person who imagined and created it, and to Claire, whose claim to it's meaning is based on her position of western privilege. This illustrates one of the distinctive premises of Orientalism, the power of the west to determine the meaning of all things Muslim which is based on a denial of Muslim agency. Muslims can be represented and spoken for by the west because they are incapable of speaking for themselves. Thus, no matter what Khan says to her, no matter how much he explains what the garden means in his terms, Claire does not and cannot understand him. His explanation is not "intelligible" 43 to her. Khan's explanation does not make any "sense" to her because it is neither in her terms, nor on her terms. It is not in her terms, the hegemonic terms of reference that constitute her Orientalist understanding of Muslims, Islam, and terrorism as essentially linked together. Secondly, it is not on her terms because it challenges her privilege within this order, the western privilege to define the war on terror discourse through Orientalism and to speak for his garden design. Thus, it is not just that Khan is unable explain what the garden design means, but rather that it can only mean what she already "knows", i.e. that all Muslims are terrorists.

The gap between his explaining and her understanding is visible to him, but not to her. Her privilege and the hegemonic configuration of meaning associated with it is invisible to her because it has been normalized as part of her privilege. However, Khan does see it and understand it. His subordinate position does allow him to understand her meaning very well. His challenge is based precisely on the fact that he understands it, but he does not agree with it as legitimate. Therefore, he chooses to subvert her position by putting forward his terms and his meaning as a counter-hegemonic practice and as a critique of Orientalism.

Related to the issue of intelligibility and the meaning of the design is the link between Muslim agency and knowledge. Who has the authority to speak for and about Muslims is closely tied to what constitutes knowledge of and about Muslims since both are integral and intertwined components of Orientalism. The exclusion of Muslim agency and subjectivity, what Muslims know, the meanings they give to themselves as well as to their experiences on 
their own terms calls into question the legitimacy of knowledge about Muslims that is presented and spoken for by western privilege. This is not to say that Khan's knowledge is "better than" Claire's, to assess competing claims of 'objectivity' of knowledge, but to point out that power and knowledge cannot be separated in the hegemonic discourse of Orientalism.

Lastly, the issues raised in this encounter are visible in the perception of Muslims in the US in the war on terror. The Islamophobic controversy over the construction of the Park 51 Muslim community center in NYC was based on the idea that it had a "hidden agenda." It was suspected as an attempt by Muslims to flaunt their "victory" in the 9/11 attacks, while claiming to build a center that would promote inter-faith dialogue and harmony. Most "suspicious" was the fact that it would also include prayer space, and therefore its supporters were hiding the fact that it was "actually" a mosque. At the base of this controversy was the Orientalist assumption about the fundamental difference of Muslims from the west, that they are a threat and that all Muslims everywhere are threats for this reason. Second, it also demonstrated the denial of Muslim agency. By accusing the supporters of Park 51 of having a "hidden agenda", critics positioned the hegemonic discourse of Orientalism against their power as Muslims to give meaning to it as a Muslim community center and a prayer space.

The Orientalist assumption of Islam as a threat and therefore an inability to believe otherwise feeds a general attitude towards Muslims as suspects and security threats. The NYPD's surveillance of Muslim college student associations and Snowden's revelations about NSA and FBI surveillance of Muslims in the US are both justified through this assumption. Muslims require watching because they are part of a suspect community and allegedly hiding their 'true colors' as threats to national security. ${ }^{44}$ Through this form of thinking, the belief in their terrorist plots is already present as a form of "knowledge." It is only a matter of "proving it" by scrutinizing and watching them long enough. The same rationale was present behind the creation of NSEERS as well.

\section{READING POWER}

Public and hidden transcripts ${ }^{45}$ provide another way to think about the contestation of meaning about Islam and Muslims in the war on terror discourse. They make visible the hegemonic configuration of power and meaning underlying this discourse and the subject positions within it. A public transcript is the record of the open interaction between dominant and subordinate actors, which includes what is said as well as what is not said. ${ }^{46} \mathrm{It}$ tends to be skewed towards the dominant discourse, through the power of the dominant actor. ${ }^{47} \mathrm{~A}$ hidden transcript is the discourse that is expressed "offstage", outside this interaction. It "consists of those offstage speeches, gestures, and practices that confirm, contradict, or inflect what appears in the public transcript." 48 The boundary between the two is a zone of contestation, constantly negotiated and challenged. It is not absolute.

While Claire represents the public transcript about Muslims and terrorism, Khan, even though the reader does not have access to his "offstage" thoughts about the conversation as it unfolds, demonstrates the hidden transcript of how Muslims understand their own position and experiences in the war on terror discourse. This hidden transcript slowly unfolds, initially through non-verbal gestures, such as his demeanor and his posture. $\mathrm{He}$ is calm, cool, without affect. He sits across the table, looking directly at Claire. Khan doesn't apologize, explain or reassure. Verbally, he uses irony to answer her questions, giving her "straight answers" which do and do not answer her questions. 
Irony functions as a way to resist the hegemony of Orientalism, while giving the appearance of conforming to its structures. Said illustrates this very aptly through a transcript of an Israeli radio broadcast at the time of the Israeli invasion of South Lebanon in 1982. It is ostensibly an interview with a captured Palestinian "terrorist," and is meant to demonstrate a "good Israeli/bad Palestinian terrorist" narrative. But the exact way in which the Palestinian answers, repeating the phrases used by the Israeli interviewer, has the effect of dramatic irony. ${ }^{49}$ For example,

Israeli broadcaster: "Tell me, Mr. Abu Leil, to which terrorist organization do you belong?"

Palestinian: "I belong to the Popular Front for the Liberation [tahrir] - I

mean Terrorization [takhrib] of Palestine."

Israeli broadcaster: "And when did you get involved in the terrorists'

organization?"

Palentinian: "When I first became aware of terrorism."

Israeli broadcaster: And what was your mission in South Lebanon?

Palestinian: "My mission was terrorism... in other words, we would enter

villages and just terrorize. And wherever there were women and children, we would terrorize. Everything and all we did was terrorism.",50

After the first apparent 'mistaken' use of the term "liberation" in the name of the organization, the Palestinian's repetitive use of the word "terrorism" highlights the gap between the way it would be understood by Israeli listeners and by what is meant by the Palestinian speaker. While the Israelis would see it as a confirmation of their understanding of the role of the PFLP, the continued use of the words "terrorism" and "terrorize" erodes their meaning. It would be significant to Palestinian listeners as a form of resistance presented as outward compliance. But this dramatic irony would be "intelligible" to them only because they can share in its meaning. They can hear the hidden transcript. It "makes sense" to them in a way that it would not to Israeli listeners.

Khan moves from irony to direct confrontation in this encounter, however. Each round and twist of the spiraling conversation brings the hidden transcript closer to the surface and into the open as the zone of contestation becomes more overt. "The first open statement of a hidden transcript, a declaration that breaches the etiquette of power relations, that breaks the apparently calm surface of silence and consent, carries the force of a symbolic declaration of war." 51 It names the power relations underlying their encounter. "So that's why we're here." ${ }^{, 52}$ Naming the contingency of this hegemonic order is about making visible that which has been, up till now, invisible, and which remains invisible to Claire till the very end because she cannot look past her own assumptions. After this point in the conversation, Khan takes a stronger position, countering hegemony directly, bringing the hidden transcript into direct, verbal confrontation with the public one.

\section{THE FINAL EXIT}

Given this discussion, how do we address the implications of Claire's abrupt, final exit from the room after Khan poses his last question: "How would you feel if I justified what happened to your husband by saying it wasn't about him but about his country and its 
policies?" Moral parallels made by Muslims can be dangerous because they destabilize the certainty of western privilege. This western privilege is the lynchpin of the hegemonic structure of Orientalism as a discourse. In this sense, we can interpret Claire's departure as what happens when western privilege is no longer the center, when its authority is not recognized, when its terms and its meaning are no longer accepted: the dynamic is ruptured. The configuration of power must change in order to accommodate this destabilizing event. One could interpret this ending as Khan having the last word, literally and figuratively. He speaks and Claire is speechless. She has no more words. More than that, it is his claim to power that leaves no room for her, literally. She has to exit. It is tempting to read this ending as a void, a sudden vacuum, as something that is missing. But Claire's exit is not the exiting of power from the discourse. Rather, it is de-centering of Orientalism as a particular hegemonic order, producing the space for a different articulation of power that does not take the west as its reference point.

\section{CONCLUSION}

This paper has attempted to demonstrate how power works, how the power of Orientalism as a hegemonic system of meaning works to define Islam and Muslims in the west today. It has tried to illustrate the link between power and the construction of knowledge in the war on terror discourse, which has reinforced and perpetuated Orientalist constructions of Muslims as violent and terrorist threats against the morally "innocent" and "good" west. The conversation between Claire and Khan is a snapshot of Orientalism and its critique, of the western privilege that Claire demonstrates and Khan's counter-hegemonic response as a Muslim exercising his agency and subjectivity.

Translating this into non-fiction, what does this mean for Muslims today? How do they speak in the decolonial space opened up through Khan's critique and simultaneously how do they create the space in which to speak? These two processes go hand in hand. This comes back to the idea of agency, of Muslim agency to define themselves as subjects in their own terms. It means creating a space for a different reading of the political, while speaking within it as well. It requires Muslims to name the contingency of the war on terror discourse and to challenge it by pointing out how the processes of securitization are at work to stigmatize and stereotype Muslims as dangerous Others.

\section{NOTES}

\footnotetext{
${ }^{1}$ George W. Bush. Presidential Address to Joint Session of Congress and American People. September 20, 2001. http://georgewbush-whitehouse.archives.gov/news/releases/2001/09/20010920-8.html Accessed March 19, 2014.

2 Richard Jackson, $W$ riting the $W$ ar on Terror: Language, Politics and Counter-terrorism, (Manchester \& New York: Manchester University Press, 2005).

3 John Carroll, Terror: A Meditation on the Meaning of September 11, (Melbourne: Scribe Publications, 2002).

${ }_{4}^{4}$ Bush, Presidential Address to the Joint Sessions of Congress.

${ }^{5}$ Bush, Presidential Address to the Joint Sessions of Congress.

${ }^{6}$ Uzma Jamil and Cécile Rousseau,"Challenging the 'Official' Story of 9/11: Community Narratives and Conspiracy Theories" Ethnicities, Vol. 11, No. 2 (2011), pp. 245-261.

${ }^{7}$ Ernesto Laclau and Chantal Mouffe. Hegemony and Socialist Strategy: Towards a Radical Democratic Politics (London: Verso, 1985).

${ }^{8}$ Chantal Mouffe, Agonistics: Thinking the World Politically (London: Verso Books, 2013), p. 2.
} 
${ }^{9}$ Edward W. Said, Orientalism, (New York: Vintage Books, 1978), p. 2.

10 Said, p. 3.

11 Said, p. 3.

12 S. Sayyid, A Fundamental Fear. 2nd edition. (London: Zed Books, 2003), p. 33.

13 Sayyid, p. 34.

${ }^{14}$ Said, p. 13.

15 Said, p. 300.

16 Said, p. 301.

${ }^{17}$ Sayyid, p. 32.

18 Mouffe, p. 2.

${ }^{19}$ Sherene Razack, Casting Out: The Eviction of Muslims from Western Law and Politics (Toronto: University of Toronto Press, 2008), p. 6.

${ }^{20}$ Razack, p. 5.

${ }^{21}$ Mahmood Mamdani, "Good Muslim, bad Muslim: A political perspective on culture and terrorism." American Anthropologist 104(3) 2002, pp. 766-775

22 Tram Nguyen, We are All Suspects Now, (Boston: Beacon Press, 2005); Louise A. Cainkar, Homeland Insecurity: The Arab American and Muslim American Experience after 9/11, (New York: Russell Sage Foundation, 2009).

${ }^{23}$ Hatem Bazian, "National Security Entry-Exit Registration System: Arabs, Muslims and Southeast Asians and Post 9/11 'Security Measures"' Islamophobia Studies Journal, Vol. 2, No. 1 (Spring 2014), pp. 82-98.

${ }^{24}$ Glenn Greenwald and Murtaza Hussain. "Under Surveillance: Meet the Muslim-American leaders the FBI and NSA have been spying on.” The Intercept. July 9, 2014.

https:// firstlook.org/theintercept/article/2014/07/09/under-surveillance/ [Accessed July 19, 2014].

${ }^{25}$ Sharon Otterman. "Developer Scales Back Plans for Muslim Center Near Ground Zero.” New York Times. April 29, 2014. http:/ / www.nytimes.com/2014/04/30/nyregion/developer-scales-back-plans-for-muslimcenter-near-ground-zero.html [Accessed July 19, 2014].

${ }^{26}$ Omid Safi. "Good Sufi, Bad Muslims.” The University of Chicago Divinity School. January 27, 2011. http://divinity.uchicago.edu/sightings/good-sufi-bad-muslims-omid-safi. [Accessed July 19, 2014].

27 Amy Waldman, The Submission, (New York: Farrar, Strauss and Giroux, 2011), p. 265.

28 Waldman, p. 265.

${ }^{29}$ Waldman, p. 265.

30 Waldman, p. 265.

31 Waldman, p. 266.

32 Waldman, p. 267.

33 Waldman, pp. 267-268.

34 Waldman, p. 268.

35 Waldman, p. 269.

36 Waldman, p. 269.

37 Waldman, p. 270.

38 Waldman, p. 270.

39 Waldman, p. 271.

40 Waldman, p. 271.

${ }^{41}$ Waldman, p. 271.

42 Waldman, p. 271.

43 Peter Winch, "Understanding a Primitive Society," American Philosophical Quarterly, Vol. 1, No. 4 (October 1964), p. 317.

44 Greenwald and Hussain, 2014.

45 James C. Scott, Domination and the Arts of Resistance: Hidden Transcripts, (New Haven: Yale University Press, 1990).

46 Scott, p. 2.

${ }^{47}$ Scott, p. 4.

48 Scott, pp. 4-5.

${ }^{49}$ Edward Said, After the Last Sky: Palestinian Lives, (London: Faber and Faber, 1986), p. 65.

50 Said, p. 65.

51 Scott, p. 8.

52 Waldman, p. 268. 